\title{
Potential of Adding Constructed Wetland/Fishpond to Waste Stabilization Ponds to Improve Helminths Removal in Morogoro Municipality, Tanzania
}

\author{
*1 OUTWATER, AH; ${ }^{2} \mathrm{ZACHARIAH,} \mathrm{A;}{ }^{3}$ NYOMORA, A; ${ }^{4}$ FRANCIS, F; ${ }^{5} \mathrm{KATIMA}$, \\ JHY \\ *Muhimbili University of Health and Allied Sciences, Department of Community Health Nursing, PO Box 65004, Dar es Salaam, Tanzania. \\ *Corresponding Author Email: anneoutwater@yahoo.com; Tel: 255 (0)713 856962 \\ ${ }^{2}$ Muhimbili University of Health and Allied Sciences, Department of Parasitology and Medical Entomology, PO Box 65011, Dar es \\ Salaam,Tanzania.Email: naayz@ymail.com \\ ${ }^{3}$ University of Dar es Salaam, Department of Botany, PO Box 35060, Dar es Salaam, Tanzania Email: agnesnyomora@gmail.com \\ ${ }^{4}$ National Institute of Medical Research, Tanga, Tanzania: ffrancis8@gmail.com \\ ${ }^{5}$ University of Dar es Salaam, College of Engineering and Technology, PO Box 35901, Dar es Salaam, Tanzania Email: \\ jamidu_katima@yahoo.co.uk
}

\begin{abstract}
A study was conducted to establish the potential of constructed wetlands in Morogoro Urban District, Tanzania, to remove helminths from wastewater. The standard wastewater treatment regime was failing to effect reliable removal of helminth eggs and larvae from six wastewater stabilization ponds. An alternative wastewater treatment regime for the ponds, coupled with a constructed wetland and a fishpond, was devised. Water, soil, and vegetable samples were tested for the presence of helminth larvae and eggs in a time series design over one growing season. From March to August 2014, experimental plots of carrots and Swiss chard were irrigated with wastewater that had been treated by the alternative wastewater treatment regime. It was found that the alternative wastewater treatment regime coupled with the constructed wetland and fishpond appeared to remove helminths completely. No helminths were found in the wastewater after it passed through the alternative system, and none were found in the market-ready carrots and chard. Numbers of helminth larvae and eggs showed evidence of seasonality, which is potentially useful knowledge for farmers in order to avoid helminth infection: almost all larvae were found at the end of the hot dry season. Monsoon rains followed and washed the helminth larvae and eggs away and none were found at the end of the season.
\end{abstract}

DOI: $\underline{\text { https://dx.doi.org/10.4314/jasem.v23i12.18 }}$

Copyright: Copyright (C) 2019 Outwater et al. This is an open access article distributed under the Creative Commons Attribution License (CCL), which permits unrestricted use, distribution, and reproduction in any medium, provided the original work is properly cited.

Dates: Received: 30 November 2019; Revised: 20 December 2019; Accepted: 23 December 2019

Keywords: wastewater stabilization ponds, constructed wetlands, helminth removal, hookworm, sewage treatment

Despite its potential dangers, the use of effluent from wastewater treatment for irrigation, has become a recommended practice. A study, for example, comparing the effects on rice cultivation of using tapwater, wastewater from Morogoro Urban Water Supply and Sanitation Authority (MORUWASA) ponds, and a combination of wastewater and NPK (nitrogen, phosphorous, potassium) fertilizer found that the wastewater alone was the most effective means of increasing rice yields (Nyomora, 2015). The primary problem of using raw or partially treated wastewater is disease transmission posed by parasitic worms; of particular importance worldwide are the helminth species Ascaris lumbricoides (roundworm), Trichuris trichiura (whipworm), and Ancylostoma duodenale and Necator americanus (hookworms) (Shuval, 1986; Zacharia et al., 2018). Bartone (1991) suggests that if World Health Organization (WHO) guidelines are routinely followed, no undue health risk of infectious disease transmission in effluent irrigation projects should arise. The MORUWASA plant was chosen as the site for intervention because it was not meeting minimum WHO standards in terms of helminth removal, and its effluent was widely used by farmers. The objective of the research study was to implement an intervention ensuring that wastewater used for irrigating vegetables was safe for farmers and the produce safe for consumers. We hypothesized that an alternative wastewater treatment regime of a constructed wetland (CW)/ fishpond coupled to the facultative pond of the waste stabilization ponds (WSP), would be more effective at decreasing the helminth load than the standard wastewater treatment regime of four additional maturation ponds (Figure 1). The broad objective of this field study was to determine whether helminths could be removed from a WSP coupled with a CW/fishpond, by evaluating the helminth load in the effluents, soil, and market-ready vegetables from farmers' fields irrigated with treated wastewater effluent. 


\section{MATERIALS AND METHODS}

A naturalistic field study was conducted over one growing season, from March through August 2014. A time series design was used to compare a standard wastewater treatment regime with an alternative regime. The study site was a MORUWASA wastewater treatment plant located at $6^{\circ} 47^{\prime} 07.28^{\prime \prime S}$ and $37^{\circ} 40^{\prime} 29.34^{\prime \prime} \mathrm{E}$ in Morogoro, Tanzania, a town of about 315,000 population. Morogoro has a tropical climate with an average annual temperature of $30^{\circ} \mathrm{C}$, highly suitable for agriculture. Typically, December to March is a hot and dry season. April to May has the period of heaviest rains, and is the most favored planting season. June to September are typically dry, and when most crops are harvested. Harvest time is followed by a period of short rains.

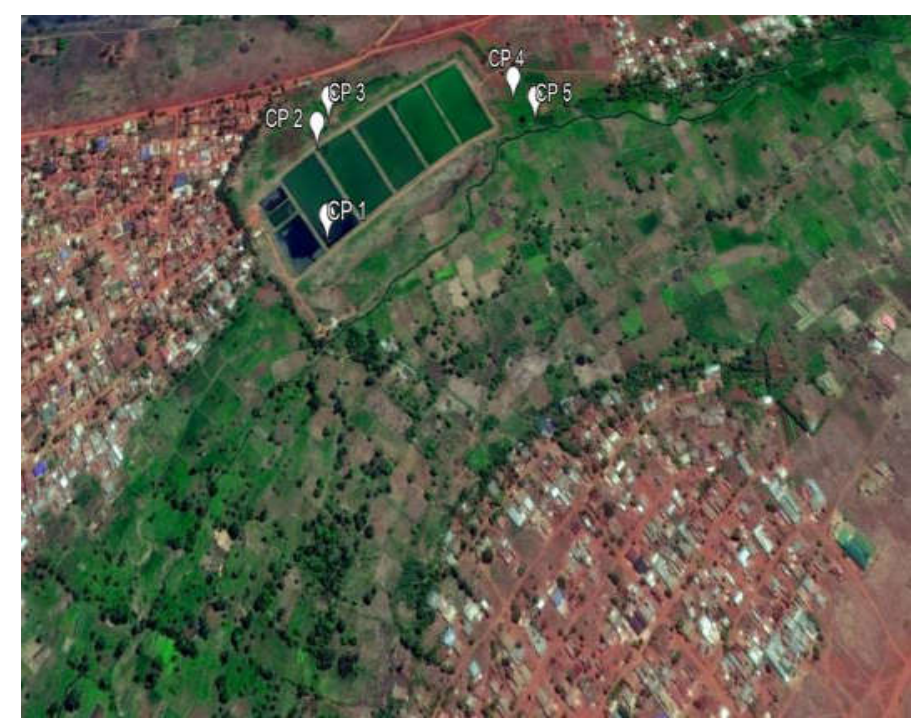

Fig 1: Site of Morogoro Urban Water Supply and Sanitation Authority treatment plant. Note: CPs indicates wastewater collection points.

The wastewater treatment plant was bordered on the north by a plateau upon which was an area of light industry, and on the south and east by rich agricultural lands in a floodplain of the Morogoro River. The floodplain was bordered by residential areas (Figure 1). The treatment plant consists of a standard treatment regime made up of a series of two faecal sludge ponds, one anaerobic pond, one facultative pond and four maturation ponds and an alternative treatment regime made up of a horizontal subsurface flow constructed wetland $(\mathrm{CW})$ and fishpond connected by an outlet of the facultative pond.

The combined volume of all ponds of the standard treatment regime was $58,000 \mathrm{~m}^{3}$, covering a total surface of 6 ha. The ponds received wastewater collected by the municipal sewerage system as well as from bowsers that collected wastewater from septic tanks unconnected to the sewerage system. The wastewater flow rate estimation was made using the float method. The measurement was done four times in 2 days. The final inlet flow rate was obtained by adding the average channel flow rate and the flow rate due to bowsers. It was determined that an average of $4516 \mathrm{~m}^{3} \mathrm{~d}^{-1}$ of wastewater flowed into the WSP via the sewer line per day. In addition, there was a direct discharge of wastewater into the WSP from four wastewater bowsers. The flow rate due to bowsers was calculated by summing the products obtained by multiplying volume of each bowser times the number of trips per day. The average daily amount of bowsered wastewater discharged into the WSP was about 95.6 $\mathrm{m}^{3}$ for a total wastewater flow rate of approximately $4612 \mathrm{~m}^{3}$ per day.

The alternative treatment regime $\mathrm{CW}$ was connected to the maturation pond with a pipe and a valve. It was designed as a rectangular structure $21 \mathrm{~m}$ long. It contained three baffle cells of $3.5 \mathrm{~m}$ each separated by a baffle wall $1 \mathrm{~m}$ wide, making a total internal width of $11.5 \mathrm{~m}$. The overall depth was $1 \mathrm{~m}$, consisting of a $0.6 \mathrm{~m}$ of metamorphic schist gravel substrate and a freeboard of $0.4 \mathrm{~m}$. The water depth in the $\mathrm{CW}$ was planned and maintained at $0.5 \mathrm{~m}$ from the bottom of the bed. It had been planted with the reed Phragmites mauritianus, 9 months earlier. The $\mathrm{CW}$ was designed for a capacity of $161 \mathrm{~m}^{3}$ per day and a retention time of 5 days.

The fishpond was irregularly shaped; it had a surface area of $112.5 \mathrm{~m}^{2}$. The pond's overall depth was $1.2 \mathrm{~m}$; the water was kept at a depth of $0.8 \mathrm{~m}$. The fishpond was stocked with tilapia fingerlings, which are indigenous to Tanzania. The effluent from the 
fishpond traveled through a polyvinylchloride pipe to irrigate the experimental plots at the farmers' fields.

Wastewater was sampled at five collection points (CP). As shown in Figure 1, collection point 1 (CP1) was where the effluent discharged from the anaerobic pond. Collection point 2 (CP2) where the wastewater flowed through the facultative pond into the maturation ponds. Collection point $3(\mathrm{CP} 3)$ was the outlet of the $\mathrm{CW}$, where it passed into the fishpond. Collection point 4 (CP4) was the outlet of the pipe in the farmers' fields. Collection point 5 (CP5) was where the final effluent of the standard treatment regime directed through a pipe reached the Morogoro River. Twenty-four-hour composite wastewater samples were collected approximately every 2 weeks, nine times from March to August, per WHO guidelines (Ayres and Mara, 1996). Samples were tested at the Muhimbili University of Health and Allied Sciences WHO supported parasitology laboratory.

The experimental plots were in farmers' fields, tilled by the farmers who were in the best position to use the MORUWASA effluent. There were 20 plots, each one-meter square. Alternate plots were irrigated with MORUWASA effluent and tap water. Soil samples started being collected after the plots had been irrigated for approximately one month. Soil collection techniques followed those prescribed by Rai et al. (2000), with soil samples being drawn from all evennumbered experimental plots six times from early April to the beginning of July. Vegetable samples were collected when they were market-ready. Samples of

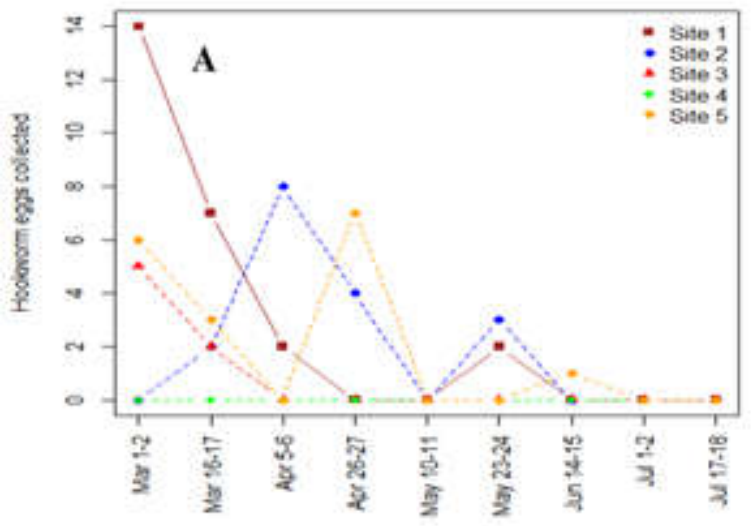

Carrots (Lactuca sativa), and Swiss chard (Beta vulgaris subsp. vulgaris) were randomly collected from even-numbered plots three times in July and August. The zinc sulphate flotation technique was used to test vegetables (Cheesbrough, 1998). Wastewater samples were analyzed using the Modified Bailenger method (Ayres and Mara, 1996). The sucrose solution flotation method was used for testing soil samples, per Rai et al. (2000). Precipitation data were gathered from World Weather Online, which reports data gathered at an official weather station about 8 kilometers from the MORUWASA site.

Microsoft Excel was used for data entry and analysis. Through measuring and charting the concentration of helminth eggs and larvae at each stage of the wastewater treatment process and usage chain, the efficacy of coupling WSPs with a CW to reduce the threat of disease transmission to farmers via irrigation water was evaluated. Descriptive statistics were used to characterize the presence of helminth eggs in wastewater, soil, and vegetables. Graphs and tables were constructed.

\section{RESULTS AND DISCUSSION}

Twenty-four-hour water samples were collected nine times from the five collection points. A total of 115 parasites were collected: 83 eggs and 32 larvae. Most eggs were collected from CP1, 42 (51\%) (Figure 2, Panel A). Non-hookworm eggs were collected only from CP1 (Figure 2, Panel B).

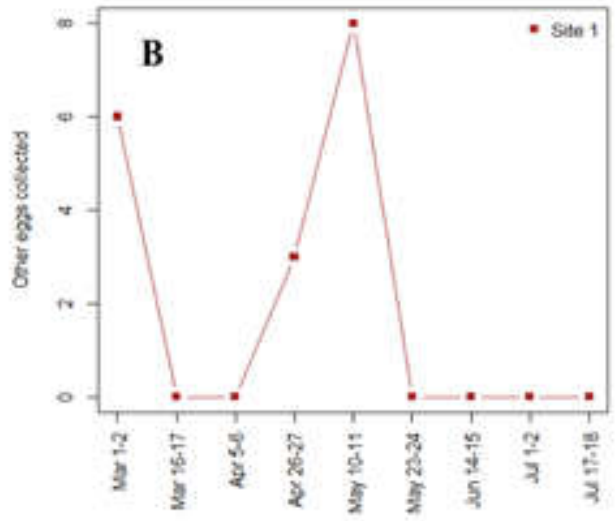

Fig 2: Change over time in number of helminth eggs collected, by collection point and date of collection, at MORUWASA

Eighty per cent of all the eggs that were collected, were hookworm eggs. More than $87 \%$ (28) of larvae were collected on the second day, spread throughout the WSPs. No eggs or larvae were detected on the last two days of data collection. Seventy-six eggs were from the standard wastewater treatment systems (CPs
$1,2,5)$ and 7 from the alternative wastewater treatment systems (CPs 3, 4). No larvae were found in the alternative system.

Figure 3 shows the number of helminth eggs and larvae collected per liter of effluent, at each sampling 
point along the standard wastewater treatment regime, for points 1, 2, and 5. It illustrates that helminth eggs and larvae were not being adequately treated by the standard wastewater treatment regime at MORUWASA. The effluent did not consistently meet WHO allowable limits for crop irrigation. No helminth eggs and larvae appear to have passed through the alternative wastewater treatment regime (Figure 4). Soil samples were tested from 10 plots six times. A Cestodes scolex and a hookworm larva were each identified once in the first soil tests. One Taenid egg was found in mid-June. Otherwise, no abnormalities were detected. Moreover, no helminth eggs or larvae were detected in the market-ready Swiss chard and carrots collected from each experimental plot. Overall, we found that the alternative system removed helminths eggs and larvae more consistently than the standard system. This finding was based on a comparison of water samples collected at CP2 (at which point the water had not yet been diverted into the two different systems); CP5, the next collection point in the standard system (where the sampled water had gone through four stabilization ponds); and CP3 (a collection point in the alternate system at which the collected water had gone through the $\mathrm{CW}$ ). The decrease in helminths per liter in the standard treatment regime was $38 \%$ of eggs and $33 \%$ of larvae; the decrease effected by the CW was $86 \%$ of eggs and $100 \%$ of larvae. Performance of the CW might be further improved by use of a mature constructed wetland, or longer CW beds (Stott, May, and Mara, 2003). Overall, the alternative wastewater treatment regime, of WSPs coupled with the CW appeared to be completely effective at removing helminth eggs and larvae from the effluent. Further, no eggs or larvae were found on the vegetables.

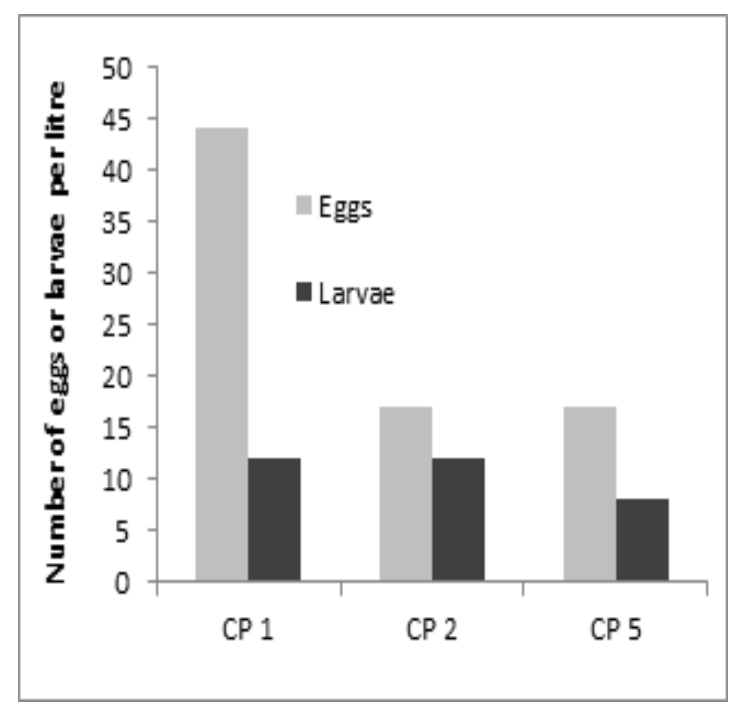

Fig 3: Helminth eggs and larvae collected per liter under standard treatment regime, at MORUWASA.

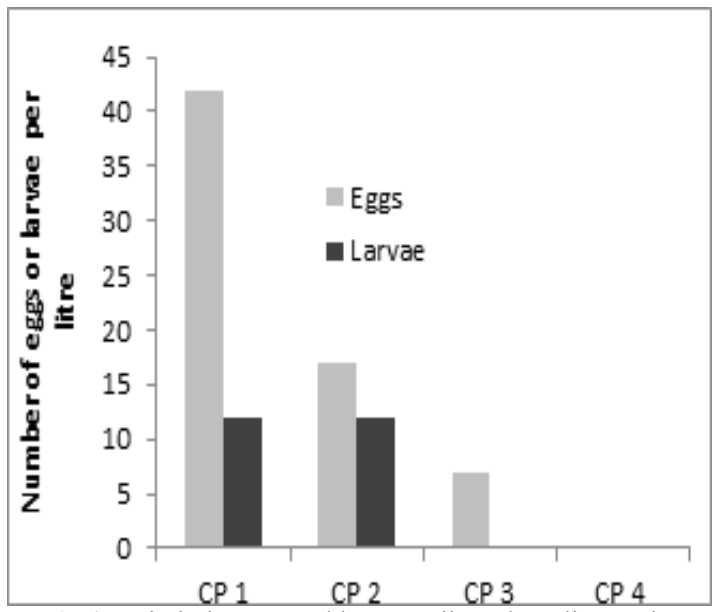

Fig 4: Helminth egg $s$ and larvae collected per liter under alternative treatment regime, at MORUWASA

The results of the present study are in accord with those found during an assessment of a coupled sewage treatment system in Spain that had been fully operational for 6 years (Molleda, Blanco, Ansola, and Luis, 2008). The Bustillo de Cea water treatment system, which combined conventional wastewater stabilization ponds with several constructed wetlands, was found to efficiently reduce many types of wastewater pathogens, including helminth eggs, which were entirely removed.

We found strong evidence of seasonal efficacy at MORUWASA based on precipitation and perhaps water temperature. Helminth larvae were only plentiful on Sampling Day 2, a time when the weather was hottest and pond effluent warmest and concentrated due to evaporation at the end of the hot dry season; it may have been a mass hatching event. An unusually high amount of rain fell in Morogoro, starting before Sampling Day 3. Between March and May 2014, precipitation was 2 times the historical average; there were four unusual rain events during which more than $70 \mathrm{~mm}$ fell in one 24-hour period; this precipitation diluted the water in the WSPs and CW and flooded the farmers' fields. It appeared that the helminths were flushed through the system by Sampling Day 3. Helminth levels remained low thereafter. The number of eggs decreased at all CPs as the growing season progressed. No eggs or larvae of any kind were found during the last 2 days of sampling. Seasonality of helminths has been recorded in WSPs in other sites. In an arid region of Morocco, for example, helminth eggs were found in higher concentrations during the hot season than in the cool season (Hajjami et al., 2012). Therefore, it appears that the riskiest time for farmers to use the effluent may be during the late dry or hot season, when 
helminth eggs and the more infective larvae are most numerous. The safest time for farmers to use the effluent may be the end of the rainy season to extend the growing season, while helminth eggs and the larvae are fewest.

There are limitations to this study. A baseline soil sample was not taken, so it is not clear if the helminths that were found were there already, or had been brought in by the irrigation Precipitation was abnormally heavy. However, since such events are predicted to become more common as a consequence of global climate change, the four events were helpful to our evaluation of the robustness of the systems. However, to confirm these results, research during a time of normal rainfall would be useful.

In conclusion, even when wastewater was burdened with excessive helminth larvae and eggs, it appeared to be helminth free, after being treated with a short series of waste stabilization ponds coupled with a constructed wetland/fishpond.

Acknowledgement: The author(s) wish to acknowledge the kind support of the Tanzania Commission for Science and Technology through a Grant provided to Professor J. Katima at the University of Dar es Salaam.

\section{REFERENCES}

AYRES, RM; MARA, DD (1996). Analysis of Wastewater for Use in Agriculture: A Laboratory Manual of Parasitological and Bacteriological Techniques. WHO, Geneva, Switzerland.

BARTON, CR (1991). International perspective on water resources management and wastewater reuse: Appropriate technologies. Water Sci Technol 23(10-12): 2039-2047.
CHEESBROUGH, M (1998). District Laboratory Practice in Tropical Countries. Cambridge University Press, New York, USA.

HAJJAMI, K; ENNAJI, MM; FOUAD, S; OUBRIM, N; KHALLAYOUNE, K; COHEN, N (2012). Assessment of helminths health risk associated with reuse of raw and treated wastewater of the Settat City (Morocco). Resources and Environment 2(5): 193-20.

MOLLEDA, P; BLANCO, I; ANSOLA, G; DE LUIS, E (2008). Removal of wastewater pathogen indicators in a constructed wetland in Leon, Spain. Ecological Engineering 3(3): 252-257.

NYOMORA, AMS (2015). Effect of treated domestic wastewater as source of irrigation water and nutrients on rice performance in Morogoro, Tanzania. J Environ and Waste Mana 2(2): 47-55.

RAI, SK; UGA, S; ONO, K; RAI, G; MATSUMURA, $\mathrm{T}$ (2000). Contamination of soil with helminth parasite eggs in Nepal. Southeast Asian J Trop Med Public Health 31(2): 388-393.

SHUVAL, HI (1986). Wastewater Irrigation in Developing Countries: Health Effects and Technical Solutions. Washington, US: World Bank.

STOTT, R; MAY, E; MARA, DD (2003). Parasite removal by natural wastewater treatment systems: Performance of waste stabilisation ponds and constructed wetlands. Water Sci Technol 48(2): 97-104.

ZACHARIA, A; OUTWATER, AH; NGASALA, B; VAN DEUN, R. (2018). Pathogenic Parasites in raw and treated wastewater in Africa: A review. Resources and Environment 8(5): 232-240 